\title{
IS HOME EDUCATION AN ALTERNATIVE TO SCHOOL EDUCATION?
}

\author{
Nadezhda V. Shuvalova ${ }^{1}$, Svetlana V. Lezhenina ${ }^{2 \star}$, Ansell Lammert ${ }^{3}$ \\ Svetlana Yu. Sapozhnikova ${ }^{4}$, Mikhail Yu. Sapozhnikov ${ }^{5}$, Antonina A. Sapozhnikova ${ }^{6}$ \\ Evgeniya V. Sapozhnikova ${ }^{7}$ \\ ${ }^{1}$ Prof, M.D., D.Sc., I. Ya. Yakovlev Chuvash State Pedagogical University, RUSSIA \\ msta77@yandex.ru \\ ${ }^{2}$ Assoc. Prof., M.D., Ph.D., I. N. Ulyanov Chuvash State University, RUSSIA, svl-8888@bk.ru \\ ${ }^{3}$ M.D., M.Sc., B.Sc.N., I. N. Ulyanov Chuvash State University, RUSSIA \\ anselllammert@seznam.cz \\ ${ }^{4}$ Assoc. Prof., M.D., Ph.D., I. N. Ulyanov Chuvash State University, RUSSIA \\ svetlanma2020m@yandex.ru \\ ${ }^{5}$ Prof, M.D., D.Sc., I. N. Ulyanov Chuvash State University, RUSSIA, mikhailsapok@yandex.ru \\ ${ }^{6}$ Prof, M.D., D.Sc., I. N. Ulyanov Chuvash State University, RUSSIA, sapozhnokova@yandex.ru \\ ${ }^{7}$ Assoc. Prof., M.D., Ph.D., I. N. Ulyanov Chuvash State University, RUSSIA \\ evgenias4pozhnikova@yandex.ru \\ ${ }^{*}$ Corresponding Author
}

\begin{abstract}
The immediate impetus for this article is the increasing media coverage of the COVID-19 pandemic, which offers homeschooling with distance learning elements as a replacement for traditional schooling. The conditions of a pandemic are not easy for educational organizations. This is due to the specifics of educational programs in schools, and also to some features of the students' families' socio-economic situations. The parents of many students have few financial means. These students may not have even basic conditions at home to systematically study remotely; for example, they may not have an equipped workplace, a computer, or a tablet connected to the Internet. In the process of distance learning, schoolchildren are much less likely to rely on help and support from their own parents. This is due both to the parents' employment in their own work and to any lack of pedagogical competence they may have to support home-schooling. The coronavirus barrier to learning is proving formidable for many students.

Some of the most serious problems associated with homeschooling are: additional costs associated with the use of the Internet, lack of high-quality and user-friendly learning materials and resources necessary for organizing online learning, lack of regulatory documents governing online learning, students' decreased learning motivation, high level of stress of school teachers (associated with the need for a "shock" transition to new teaching practices and technologies), and excessive intensification of school teachers' workloads (caused by the development of new educational and information and communication technologies and the need to maintain a new mode of communication with students).

Purpose of the study: to carry out a theoretical analysis and generalization of modern scientific and methodological literature on the problem of home education with elements of distance learning in conditions of mass isolation due to the epidemiological situation associated with the novel coronavirus pandemic.

The results of the literature data analysis prove that neither the more complex social world of the school class nor the educational trajectory impedes effective schooling. It proves that the differences between the function of primary socialization in the family and secondary socialization at school, and their management, are a necessary condition for the healthy development of a child.
\end{abstract}


What form is effective for quality education of children? The answer depends on what goal we set for the educational process. There is a general consensus that it is about good socialization for the child, i.e. about becoming a competent (autonomous) member of their community. This requires mastering basic knowledge and skills. Thus, attending school is a prerequisite for the child's socialization in society, as well as contributing to acquiring a quality education that matches the established trajectory of the educational process. The arguments for unrestricted expansion of home education do not stand up to a high level of scrutiny. However, this does not mean that it should be banned. The authors of this article believe that home education can only be used as an alternative to school education. School education should not be completely replaced by home education. Home education can only be used for a short time, and in justified cases (for example, in the context of the COVID-19 pandemic), with full awareness of the problems it can pose.

Keywords: home education, home education and pandemic, home education problems.

\section{RELEVANCE: PURPOSE OF THE STUDY - RESEARCH METHODS}

Relevance: The immediate impetus for this article is the increasing media coverage of the COVID-19 pandemic, which offers homeschooling with distance learning elements as a replacement for traditional schooling. The conditions of a pandemic are not easy for educational organizations. This is due to the specifics of educational programs in schools, and also to some features of the students' families' socioeconomic situations. The parents of many students have few financial means. These students may not have even basic conditions at home to systematically study remotely; for example, they may not have an equipped workplace, a computer, or a tablet connected to the Internet. In the process of distance learning, schoolchildren are much less likely to rely on help and support from their own parents. This is due both to the parents' employment in their own work and to any lack of pedagogical competence they may have to support home-schooling. The coronavirus barrier to learning is proving formidable for many students.

Purpose of the study: to carry out a theoretical analysis and generalization of modern scientific and methodological literature on the problem of home education with elements of distance learning in conditions of mass isolation due to the epidemiological situation associated with the novel coronavirus pandemic.

Scientific question: Is home education with elements of distance learning an alternative to school education?

Research methods: The work used literary-analytical and generalizing research methods.

\section{RESULTS}

Violation of the educational process: Governments around the world have decided to close educational institutions in an attempt to contain the global COVID-19 pandemic. According to UNESCO, 188 states closed schools nationwide, affecting $91.3 \%$ of students' worldwide (1.58 billion people) (Epidemiya, 2020; Distancionnoe, 1995).

School closures, even temporary ones, have great social and economic consequences, especially for the poor.

1. Interrupted learning: children and youth are deprived of opportunities for growth and development, this mainly affects students from low-income families who do not have opportunities for education outside of school (Distancionnoe, 1995).

2. Meals: Many children receive free or reduced price meals provided by schools.

3. Problems in childcare: in the absence of alternative options, working parents are forced to leave their children alone, which can be dangerous to their life and health.

4. High economic costs: working parents are forced to skip work to care for their children, which in many cases results in loss of wages and negatively affects productivity.

5. Additional burden on the health care system: women make up the majority of health workers and are often unable to attend work due to the need for childcare. This means that many health care workers are not in the facilities where they are most needed during a health crisis (Epidemiya, 2020; Domrachev, 1994).

6. Increased pressure on schools that remain open: localized closures of some schools burden other schools 
as parents and officials reroute children to open schools.

7. Dropout rates tend to rise: ensuring that children and young people returned to schools after their opening is a challenge (Epidemiya, 2020; Nikitin, 1998).

8. Social isolation: schools are centers of social activity and human interaction. Many children and young people are deprived of the social contacts that are essential for learning and development.

Common problems in the transition to a distance education system: The World Bank draws attention to the challenges countries are facing in the transition to distance education, and also identifies the challenges for all affected groups - students, teachers, parents and decision-makers.

1. At the moment, there are very few education systems (even among the most high-quality ones) that have good technical support to make a quick transition to distance learning. Success is more likely in countries where distance education was widely used before the pandemic (Epidemiya, 2020; Otkrytoe, 2004, p. 13).

2. The transition to distance learning is costly. Of course, it is important to ensure the infrastructure potential. But a much greater challenge is the support of teachers; providing high quality and relevant digital learning materials; developing students' digital skills to effectively use technology for learning; implementation of auxiliary data and information management systems.

3. The shift to distance learning raises concerns about social stratification. In practice, online learning provides a disproportionate benefit to students with an inherently more advantageous position (for example, in the case of stratification along the line between rich and poor; those living in the city - living in rural areas; with good academic performance - with poor academic performance) (Epidemiya, 2020; Polat and Petrov).

4. Most students will have difficulty making the transition to distance education. This means that for most schoolchildren and students, education will be of less benefit. This aspect is especially relevant for children in poor areas with limited or no internet access. Students with prior distance learning experience will also have an advantage.

5. When switching to distance learning, you need to keep in mind that at first students will show weaker results. This is due to the lack of experience in interacting with the tools and learning processes, the lack of an enabling environment for online learning at home. After some time, both students and teachers will face the challenge of lack of motivation (Epidemiya, 2020; Polat, Razvitie; Polat, Distancionnoe).

6. Educational institutions will be faced with the question of choosing which subjects to teach online, and which ones to leave to students for independent development. Some subjects, school activities and approaches will be difficult to transfer to the online environment.

7. Only a few teachers will be able to make a quick and effective transition to the online learning model, since the teaching process remotely and in the classroom differ significantly from each other. In this regard, teachers will need support and additional training.

8. In a distance learning setting, parents play a key role in supporting their children. Even in the best of circumstances, most parents are ill-equipped to provide effective support. Especially in cases where they themselves do not have sufficient technical skills. Parents may have multiple children attending educational institutions, so they will face the problem of distributing available devices between them. UNESCO also draws attention to the additional burden on parents with disabilities and on parents in critical sectors of the epidemic (Epidemiya, 2020; Tihomirov, 1997; Hutorskij, 2000).

9. Decision-makers are more dependent on two factors: the preparedness of the existing education system for the transition to online learning and the amount of time before the closure of educational institutions. Today, the world community has not developed enough experience to determine the volume and mechanisms of financing the online education system.

\section{CONCLUSIONS}

The results of the analysis of literature data prove that neither the more complex social world of the school class nor the educational trajectory impedes effective learning. This proves that the differences between the function of primary socialization in the family and secondary socialization in school and their management are a necessary condition for the healthy development of the child.

What form is effective for quality education of children? The answer depends on what goal we set for the educational process. There is a general consensus that we are talking about good socialization of the child, that is, about becoming a competent (autonomous) member of their community. This requires mastering 
basic knowledge and skills. Thus, attending school is a prerequisite for the child's socialization in society, and also contributes to obtaining a quality education that corresponds to the established trajectory of the educational process.

The case for unlimited expansion of home education does not stand up to scrutiny. However, this does not mean that it should be banned. The authors of the article believe that home education can only be used as an alternative to schooling. School education should not be completely replaced by home education. Homeschooling can only be used for a short time and in justified cases (for example, in the context of the COVID-19 pandemic), with full awareness of the problems it can pose.

\section{RECOMMENDATIONS}

1. To reduce the burden of caring for the children of citizens employed in critical industries during the fight against the epidemic (doctors, pharmacists, police, firefighters, transport workers, etc.), it is necessary to open schools and kindergartens for children of these categories citizens.

2. To ensure continuous and universal education, it is necessary to deploy a national electronic educational platform and provide access to it for students (electronic devices, access to the Internet).

3. Take measures to prevent an increase in the number of street children.

4. Remove administrative barriers to the international exchange of knowledge and experience, scientific research in the development of vaccines and drugs against COVID-19, tests for the accelerated detection of coronavirus.

\section{REFERENCE LIST}

1. Epidemiya koronavirusa: vozdejstvie na sferu obrazovaniya. (2020). Dajdzhest podgotovlen Departamentom mezhdunarodnogo i regional'nogo sotrudnichestva SP RF.

2. Distancionnoe obrazovanie. (1995). Problemy informatizacii vysshej shkoly. Byulleten', 3.

3. Distancionnoe obrazovanie. Lekcii. [Electronic resource]. URL: http://www.iet.mesi.ru/dis/oglo.htm

4. Domrachev, V.G. (1994). Distancionnoe obuchenie: vozmozhnosti i perspektivy. Vyssh. obraz. v Rossii, 3.

5. Nikitin, A.B., Sinegal, V.S., Sorockij, V.A., Cikin I.A. (1998). Interaktivnye informacionnye tekhnologii na osnove Web-serverov i sistem komp'yuternoj videokonferencsvyazi. Distancionnoe obuchenie, 1.

6. Otkrytoe i distancionnoe obuchenie: tendencii, politika i strategii. (2004). Moskva: Izd. INT.

7. Polat, E.S., Petrov, A.E. Distancionnoe obuchenie kakim emu byt'? [Electronic resource]. URL: http://distant.ioso.ru/library/publication/razvitie.htm

8. Polat, E.S. Razvitie distancionnoj formy obucheniya v shkol'nom obrazovaniya. [Electronic resource]. URL: http://distant.ioso.ru/library/publication/concept.htm

9. Polat, E.S. Distancionnoe obuchenie: organizacionnye i pedagogicheskie aspekty. [Electronic resource]. URL: http://distant.ioso.ru/library/publication/6.htm

10. Tihomirov, V.P. (1997). DO: istoriya, ekonomika, tendencii. Distancionnoe obuchenie, 2.

11. Hutorskij, A.V. (2000). Internet v shkole. Praktikum po distancionnomu obucheniyu. Moskva: IOSO RAO. 